\title{
Cytosine Arabinoside Kills Postmitotic Neurons: Evidence That Deoxycytidine May Have a Role in Neuronal Survival That Is Independent of DNA Synthesis
}

\author{
Thomas L. Wallace ${ }^{1}$ and Eugene M. Johnson, Jr. ${ }^{2}$ \\ ${ }^{1}$ Center for Biotechnology, Baylor College of Medicine, and Houston Biotechnology Incorporated, The Woodlands, Texas \\ 77381, and 2Department of Pharmacology, Washington University School of Medicine, St. Louis, Missouri 63110
}

Cytosine arabinoside (ARA C), a competitive inhibitor of the incorporation of 2'-deoxycytidine into DNA in other cell types, caused a concentration-dependent inhibition of $\mathrm{KCl}$-and insulin-stimulated survival of postmitotic ciliary parasympathetic ganglion neurons, and the nerve growth factor (NGF)stimulated survival of postmitotic dorsal root ganglion (DRG) sensory neurons in vitro. The $\mathrm{IC}_{50}$ for survival was $2 \times 10^{-8}$ $M$ for both types of neurons after $4 \mathrm{~d}$ under the culture conditions used. The inhibition of DRG survival by ARA $C$ in the presence of varying concentrations of NGF indicated that ARA $C$ acted as an apparent noncompetitive antagonist of NGF. This cytotoxic effect of ARA C was blocked by 2'deoxycytidine, but not by cytosine, 2'-deoxyadenosine, 2'deoxyguanosine, or 2'-deoxythymine, indicating that ARA C was interfering with a deoxycytidine-specific survival process. Cytidine could block ARA C toxicity, but it was 40 times less potent than 2'-deoxycytidine. The blockade of the cytotoxic effect of ARA C by 2'-deoxycytidine indicated that 2 '-deoxycytidine was an apparent competitive antagonist of ARA C toxicity. 2'-Deoxycytidine, by itself, was not survivalpromoting. Other antimitotic agents, such as adenine arabinoside, thymine arabinoside, 5-fluorodeoxyuridine, 5-bromodeoxycytidine, 5-azadeoxycytidine, and aphidicolin had no effect on neuronal survival at a concentration 5000 times the $E C_{50}$ of ARA C, indicating that inhibition of DNA synthesis or repair was probably not the mechanism by which ARA C inhibited neuronal survival and that other 2'-deoxynucleosides were not involved in the survival-promoting process. Nitrobenzylthioinosine, an inhibitor of 2'-deoxycytidine and ARA C membrane transport in other cell types, inhibited the cytotoxic effect of ARA C in neurons, suggesting that ARA $C$ entered the neurons through a similar transport mechanism and that ARA $C$ needed to gain access to the inside of the neuron to be effective. These results indicate that ARA $C$, in addition to being an antimitotic agent for dividing cells, is also cytotoxic for postmitotic neurons. This inhibition of neuronal survival by ARA $C$ is hypothesized to be due to inhibition of a $2^{\prime}$-deoxycytidine-dependent process that is

\footnotetext{
Received Nov. 17, 1987; revised June 7, 1988; accepted June 8, 1988.

We wish to thank Ms. Patricia Osborne for her technical assistance. This work was supported by PHS Research Grants NS18071 and P50-AG05681. T.L.W. was supported, in part, by PHS Training Grant T32NS07129.

Correspondence should be addressed to Thomas L. Wallace, Ph.D., Baylor College of Medicine, Center for Biotechnology, 4000 Research Forest Drive, The Woodlands, TX 77381.

Copyright $@ 1989$ Society for Neuroscience 0270-6474/89/010115-10\$02.00/0
}

independent of DNA synthesis or repair. Thus, 2'-deoxycytidine may have an important and previously unrecognized role in cellular function that in the case of neurons is critical for survival.

Neuronal survival depends upon extracellular neurotrophic factors derived from target tissues, and many such factors are believed to exist, each directed toward a specific neuronal type or several types. Nerve growth factor (NGF) has been shown to be important in vivo for the differentiation and survival of sympathetic, dorsal root ganglion (DRG) sensory, and probably certain CNS cholinergic neurons (Levi-Montalcini and Angeletti, 1968; Johnson et al., 1980; Hefti et al., 1985). $\Lambda$ number of other factors have been highly purified and shown to have survival-promoting effects on specific neuronal types in vitro (Barde et al., 1982; Barbin et al., 1984; Morrison et al., 1986; Wallace and Johnson, 1987). The molecular mechanism by which these factors, even the well-studied NGF, maintain the survival of neurons is not understood, but it is possible that a number of different neurotrophic factors share common intracellular mediators. A number of substances have been identified that may have a role in neuronal survival and include the $\mathrm{Na}^{+}, \mathrm{K}^{+}$pump (Skaper et al., 1986), protein kinase C (Montz et al., 1985), methyltransferase (Acheson et al., 1986), cAMP (Rydel and Greene, 1988), and ras p21 (Hagag et al., 1986).

We report in this paper data suggesting that 2'-deoxycytidine, in contrast to other $2^{\prime}$-deoxynucleosides, may be a critical factor in the survival of postmitotic peripheral neurons and that this involvement appears to be independent of DNA synthesis or repair. Cytosine arabinoside (ARA C), which is a structural analog of $2^{\prime}$-deoxycytidine, had potent cytotoxic effects on parasympathetic and DRG sensory neurons, whereas other antimetabolite DNA synthesis inhibitors had no effect on neuronal survival at 5000-fold higher concentrations. ARA C differs from 2 -deoxycytidine by having an arabinose sugar in place of the 2 '-dcoxyribose sugar. This indicates that 2'-dcoxycytidine is important in neuronal survival and that its role in cellular function may extend beyond that of a metabolic precursor of DNA.

\section{Materials and Methods}

Materials. Insulin was a gift of Eli Lilly Co. (Indianapolis, IN). Eagle's minimum essential medium (MEM), fetal calf serum, and trypsin were purchased from Gibco (Grand Island, NY). Collagenase (type 4) was purchased from Cooper Biomedical (Malvern, PA). NGF (2.5S) was prepared by the method of Bocchini and Angeletti (1969). All other reagents were purchased from Sigma Chemical Co. (St. Louis).

Methods. Parasympathetic ciliary or DRG were taken from chicken 
embryos that had been incubated for $8 \mathrm{~d}(\mathrm{~F} 8)$ at $37^{\circ} \mathrm{C}$. This age is one at which the neurons are postmitotic. The birthdate (time at which the neuron undergoes terminal mitosis) is E4.5 (ciliary) and E5 (DRG) in chickens (Rohrer and Thoenen, 1987). E8 neurons were used because very few non-neuronal cells were obtained upon plating at this age, even in the absence of antimitotic agents. Ciliary ganglia were digested by a 30 min incubation at $37^{\circ} \mathrm{C}$ in trypsin $(0.0125 \%)$, and DRG were digested by a 20 min incubation at $37^{\circ} \mathrm{C}$ with collagenase (type 4 ) followed by a $10 \mathrm{~min}$ incubation at $37^{\circ} \mathrm{C}$ with trypsin $(0.0625 \%)$. Ganglia were dissociated into single cells by trituration with a small-bore pipet. Neurons were incubated at $37^{\circ} \mathrm{C}$ in $0.35 \mathrm{ml}$ of medium on a double layer of air-dried, rat tail collagen in 48 well plastic dishes (Costar 3548) in 95\% air, 5\% $\mathrm{CO}_{2}$. The medium included Eagle's MEM, 100 units $/ \mathrm{ml}$ of penicillin, $100 \mu \mathrm{g} / \mathrm{ml}$ of streptomycin, and $10 \%$ fetal calf serum. Insulin served as the trophic factor for ciliary neurons and NGF for DRG neurons. $\mathrm{KCl}$ (35 mm) was also included in the ciliary neuron medium. Plating efficiency, determined $2 \mathrm{hr}$ after adding the neurons to the wells, was usually about $70 \%$.

Ciliary and DRG neurons were cultured for $4 \mathrm{~d}$ at $37^{\circ} \mathrm{C}$ and then evaluated for survival. Neurons were fixed in $2 \%$ glutaraldehyde in PBS, and the mean number of surviving neurons was determined in 15 fields using an inverted microscope with a phase-contrast objective (Barbin et al., 1984). Neurons could easily be distinguished from non-neurons in these cultures. Viable neurons were round and phase bright, whereas dead neurons were crenated and phase dark. Survival was expressed as the mean number of surviving neurons per well.

\section{Results}

Effect of insulin on the survival of parasympathetic neurons

The rationale for the experiments presented in this paper is based on a serendipitous initial finding. Experiments were being performed in which various cell types were being grown in a defined, serum-free medium (HB101; Hana Biologicals, Inc.). The conditioned medium from these cells was being tested for survival-promoting activity on ciliary ncurons incubated in a medium that would not support neuronal survival. The ciliary neuron medium contained Eagle's MEM, 10\% serum, antibiotics, $\mathrm{KCl}(35 \mathrm{~mm})$, and ARA C $\left(10^{-5} \mathrm{M}\right)$. The ARA C was routinely added with the rationale of killing non-neuronal cells that could confuse a search for neurotrophic activity. We observed, unexpectedly, that HB101 medium alone (not conditioned) possessed survival-promoting activity. HB101 medium is composed of RPMI 1640, NCTC (a supplement containing amino acids, vitamins, cofactors, antioxidants, and $2^{\prime}$-deoxynucleosides), and 3 proteins (insulin, transferrin, and BSA). In order to determine which of the components had survival-promoting activity, systematic experiments were performed to determine which component(s) had the ability to maintain the survival of E8 chicken ciliary neurons in vitro under these conditions. Two components were found to maintain survival: $2^{\prime}$-deoxycytidine and insulin. The $2^{\prime}$-deoxycytidine in the HB101 medium was found to act by blocking the cytotoxic effect of ARA C present in the ciliary neuron medium and is presented in further sections, whereas insulin was found to directly stimulate neuronal survival. Insulin-stimulated survival of neurons has been reported previously (Bottenstein et al., 1980; Collins and Dawson, 1983; Skaper et al., 1984). An initial experiment was performed to determine the range of effective concentrations of the insulin and is presented in Figure 1. Ciliary neurons were cultured in Eagle's MEM containing 10\% serum, $35 \mathrm{~mm} \mathrm{KCl}$, and antibiotics as described in Materials and Methods. When the ciliary neurons were cultured in the presence of $35 \mathrm{mM} \mathrm{KCl}$, but in the absence of ARA C and insulin, there was a basal level of survival after $4 \mathrm{~d}$, represented by the zero concentration point (Fig. 1). The ability of $\mathrm{KCl}$ to support the survival of ciliary neurons is a phenomenon that has been reported previously by Nishi and
Berg (1981). In the presence of $35 \mathrm{~mm} \mathrm{KCl}$, insulin caused a logarithmic increase in survival up to $500 \mathrm{mU}$ insulin $/ \mathrm{ml}$, representing a 3.5 -fold increase at the highest concentration. By contrast, a $25,000 \times g$ supernatant fraction of pig lung caused an 8 -fold increase in neuronal survival in the same experiment. We have previously reported pig lung to contain high concentrations of parasympathetic neurotrophic activity (Wallace and Johnson, 1986, 1987). With insulin, maximal survival was apparently not achieved, even at the highest concentration of insulin used $\left(500 \mathrm{mU} / \mathrm{ml} ; 6.5 \times 10^{-6} \mathrm{M}\right)$. Insulin caused the outgrowth of neurites from some ciliary neurons, but this was not characterized further. Insulin at a concentration of $50 \mathrm{mU} / \mathrm{ml}$, which gives a 3-fold stimulation of survival, was used as the trophic factor to maintain survival of neurons in further experiments using ciliary neurons. The actual importance of insulin as an in vivo neurotrophic factor for parasympathetic neurons is questionable because of its relatively low concentration in the blood compared with the concentration needed to see significant neuronal survival. It was simply used here as a purified survival-promoting factor for further studies on the role of $2^{\prime}$-deoxycytidine in the survival of ciliary neurons.

\section{Concentration-response effect of $A R A C$ on the survival of parasympathetic neurons}

As previously discussed, $2^{\prime}$-deoxycytidine was one of the components of the HB10l medium that had survival-promoting effects on ciliary neurons under the culture conditions used, which included $\mathrm{KCl}(35 \mathrm{~mm})$ and ARA C $\left(10^{-5} \mathrm{M}\right)$. Normally, it would be predicted that ARA C (and other agents that inhibit DNA synthesis) would not exert deleterious effects on postmitotic neurons. An experiment investigating the concentrationresponse effect of ARA $C$ on survival of ciliary neurons was performed in which $\mathrm{E} 8$ chicken ciliary neurons were incubated for $4 \mathrm{~d}$ in the presence of varying concentrations of ARA C (Fig. 2). Survival was maintained with either $\mathrm{KCl}(35 \mathrm{~mm})$ or $\mathrm{KCl}$ plus insulin $(50 \mathrm{mU} / \mathrm{ml})$. To determine the number of surviving neurons, the neurons were fixed in glutaraldehyde and counted as described in Materials and Methods. The results showed that ARA C caused a concentration-dependent decrease in neuronal survival and that it was very potent. Fifty percent inhibition $\left(\mathrm{IC}_{50}\right)$ was observed at $2 \times 10^{-8} \mathrm{M}$ when the neurons were incubated in either $\mathrm{KCl}$ or $\mathrm{KCl}$ plus insulin. Thus, the ciliary neurons were very sensitive to low concentrations of ARA $C$ in the presence of both agents, $\mathrm{KCl}$ and insulin.

\section{Concentration-response relationship of the cytotoxic effect of $A R A C$ on DRG neurons and its blockade by 2'-deoxycytidine}

For the purpose of determining whether ARA $C$ is toxic for another neuronal type that is dependent on a different trophic factor, a similar experiment was carried out using E8 chicken DRG neurons that were cultured with purified 2.5S mouse NGF $(10 \mathrm{ng} / \mathrm{ml})$. DRG neurons were incubated with $\mathrm{NGF}$ for $4 \mathrm{~d}$ with varying concentrations of ARA $C\left(10^{-9}-10^{-4} \mathrm{M}\right)$ in the absence or presence of $2^{\prime}$-deoxycytidine $\left(10^{-4} \mathrm{M}\right)$ and then evaluated for survival as described in Materials and Methods. The results showed that ARA $C$ caused a concentration-dependent inhibition of DRG neuron survival with an $\mathrm{IC}_{50}=2 \times 10^{-8} \mathrm{M}$ (Fig. 3), indicating that, like ciliary neurons, DRG neurons were very sensitive to ARA C. It should be noted, however, that we have observed that the concentration dependence of ARA $C$ toxicity can vary with culture conditions. In particular, it would appear that the variable amount of $2^{\prime}$-deoxycytidine in sera will 


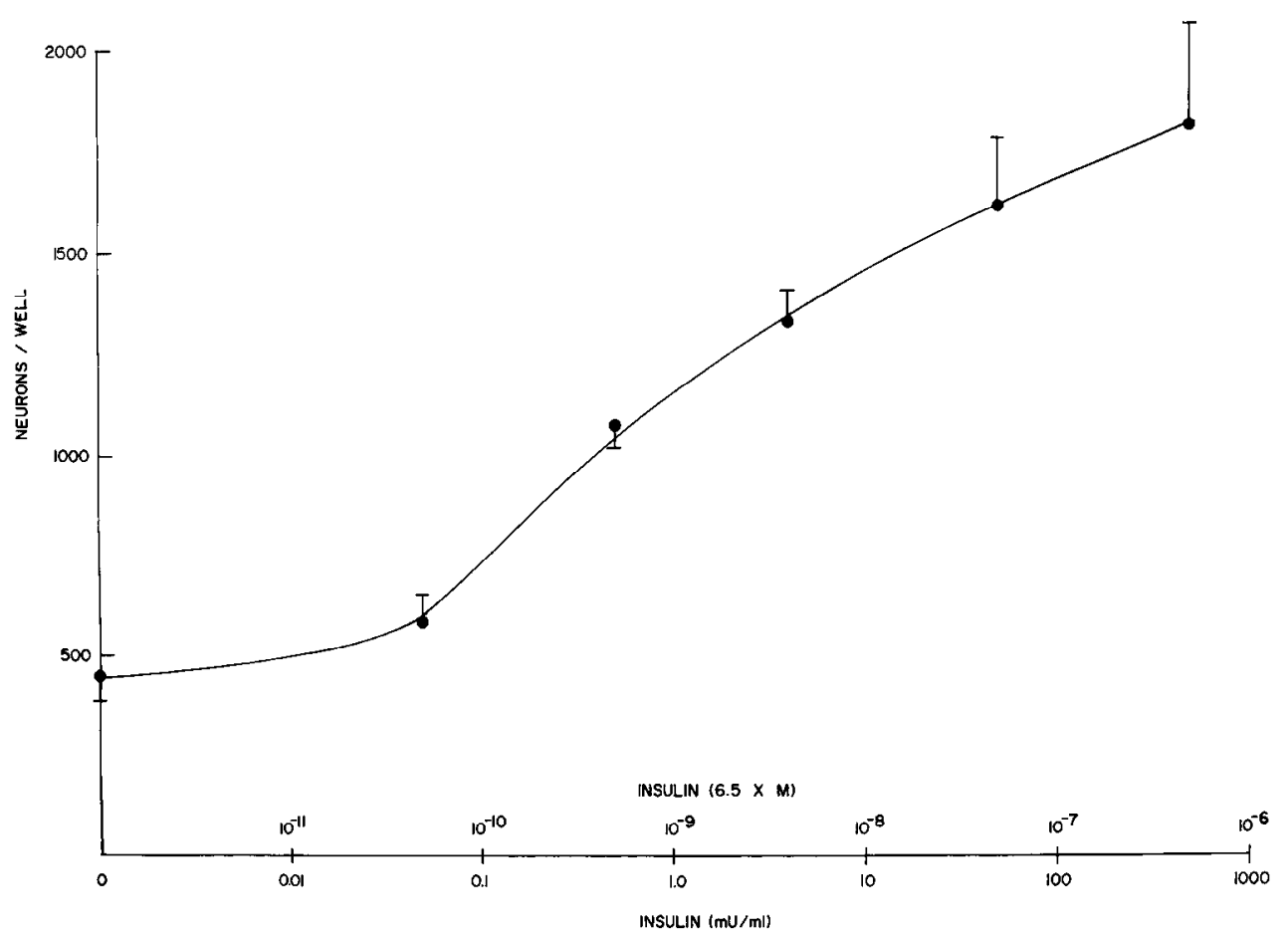

Figure 1. Concentration-response ef fect of insulin on ciliary neurons. Dissociated $\mathrm{E} 8$ chicken ciliary neurons were incubated for $4 \mathrm{~d}$ in medium containing porcine insulin present at varying concentrations and $35 \mathrm{~mm} \mathrm{KCl}$, then fixed in glutaraldehyde, and counted. No ARA C was present. 2.02 ganglion equivalents of dissociated neurons were plated per well. Values represent means \pm SE of 4 replicates. affect the apparent toxicity of ARA C. Although the concentration of $2^{\prime}$-deoxycytidine in the serum was not measured, $2^{\prime}$ deoxycytidine is present at concentrations of $0.5-4.0 \times 10^{-6} \mathrm{M}$ in human plasma (Danhauser and Rustum, 1980). The cytotoxic effect of ARA $C$ on the DRG neurons was blocked by 2 '-deoxycytidine, suggesting that survival of DRG neurons may also normally be dependent on 2 -deoxycytidine or on a 2 '-deoxycytidine-dependent process. Similar results were obtained with ciliary neurons (data not shown). In addition, the cytotoxic effect of ARA $C$ on the non-neuronal cells that were present was also reversed by $2^{\prime}$-deoxycytidine. Thus, ARA $C$ kills both ciliary and DRG neurons in a $2^{\prime}$-deoxycytidine-reversible manner, suggesting that there may be a survival pathway common to both neuronal types, even though the trophic factors used to maintain the survival of these neurons were different.

Effect of 2'-deoxycytidine on the survival of ciliary and $D R G$ neurons

The ability of $2^{\prime}$-deoxycytidine to prevent the neurotoxic effects of ARA C led to the question of whether $2^{\prime}$-deoxycytidine by

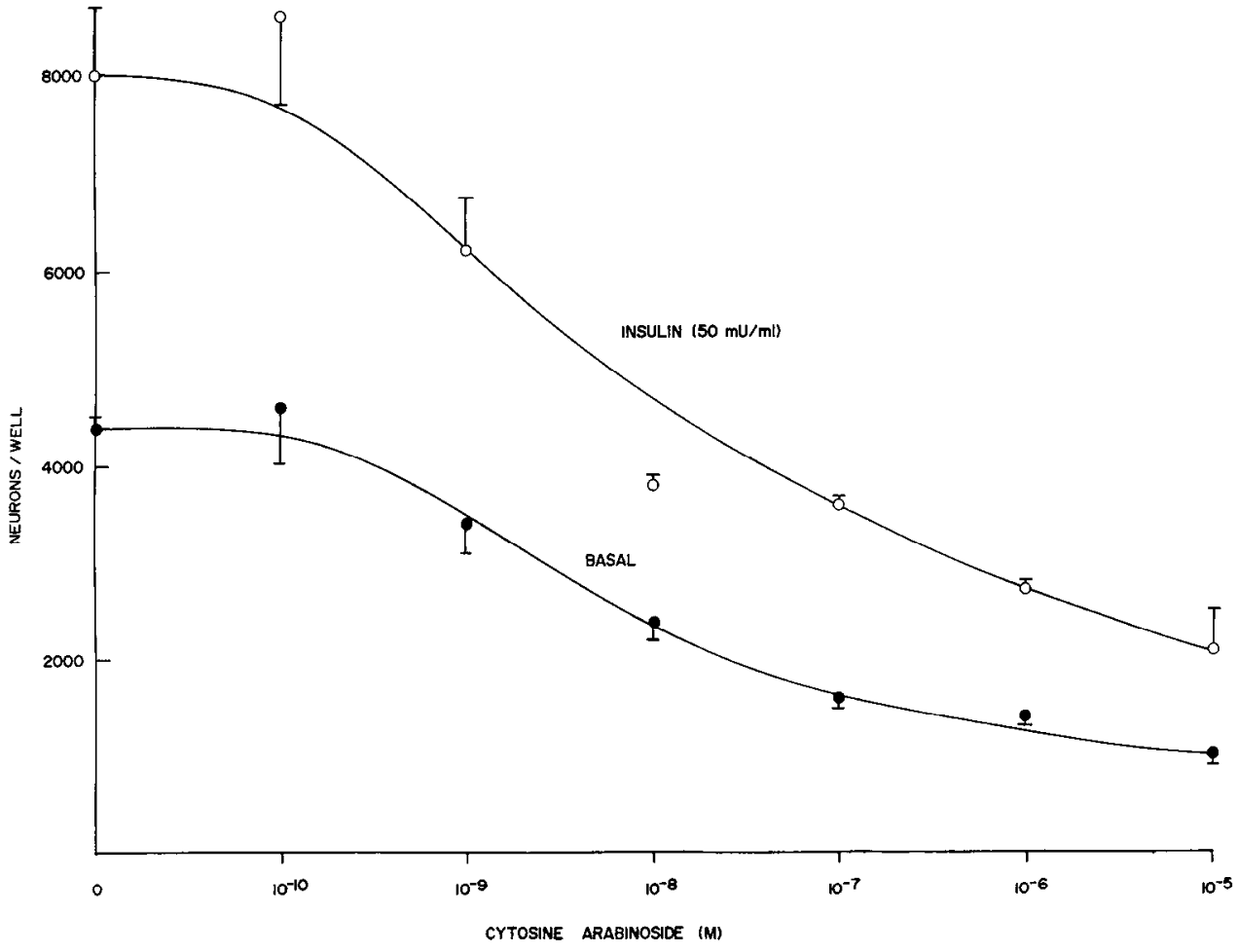

Figure 2. Concentration-response effect of cytosine arabinoside on survival of ciliary neurons. Dissociated E8 chicken ciliary neurons were incubated for $4 \mathrm{~d}$ in $35 \mathrm{~mm} \mathrm{KCl}$ (basal, $\bullet$ ) or in porcine insulin $(50 \mathrm{mU} / \mathrm{ml})$ and $35 \mathrm{~mm}$ $\mathrm{KCl}(\mathrm{O})$, and varying concentrations of ARA $C$, then fixed in glutaraldehyde, and counted. 2.9 ganglion equivalents of dissociated neurons were plated per well. Values represent means $\pm \mathrm{SE}$ of 4 replicates. 
Figure 3. Concentration-response effect of ARA C on DRG neurons in the absence or presence of 2'-deoxycytidine. Dissociated E8 chicken DRG neurons were incubated for $4 \mathrm{~d}$ with 10 $\mathrm{ng} / \mathrm{ml}$ of $2.5 \mathrm{~S} \mathrm{NGF}$ and varying concentrations of ARA $C$ in the absence $(0)$ or presence $(O)$ of $10^{-4} \mathrm{M} 2^{\prime}$-deoxycytidine, then fixed in glutaraldehyde, and counted. 1.21 ganglion equivalents of neurons were plated per well. There was no survival in the absence of NGF. Values represent means $\pm S E$ of 4 replicates.

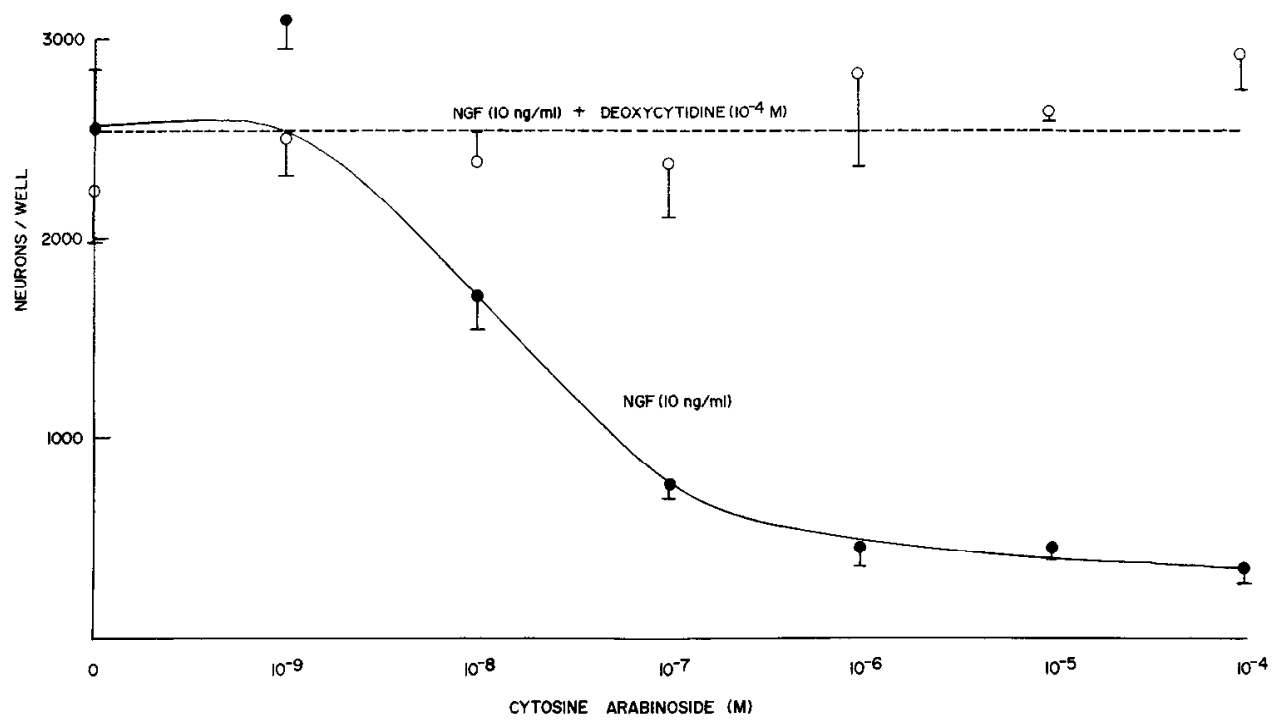

itself had survival-promoling effects on ciliary or DRG neurons. E8 ciliary or DRG neurons were incubated for $4 \mathrm{~d}$ in the presence of $2^{\prime}$-deoxycytidine $\left(10^{-3} \mathrm{M}\right)$ in serum-containing medium and then evaluated for survival. NGF $(100 \mathrm{ng} / \mathrm{ml})$ and a $25,000 \times$ $g$ pig lung supernatant fraction were used as positive controls for DRG and ciliary neurons, respectively. The results showed that 2'-deoxycytidine had no survival-promoting effects on either ciliary or DRG neurons, whereas NGF maintained the survival of DRG neurons and pig lung supernatant fraction maintained the survival of ciliary neurons (Table 1). Furthermore, $2^{\prime}$-deoxycytidine had no survival-promoting effect on ciliary neurons cultured in serum-free medium (data not shown).

Ability of 2'-deoxycytidine and its nucleotides, cytidine, cylosine, or other 2'-deoxynucleosides to block the cytotoxic effect of $A R A C$ on ciliary and DRG neurons

It was of interest to determine if $2^{\prime}$-deoxycytidine nucleotides, metabolic precursors of $2^{\prime}$-deoxycytidine, or other $2^{\prime}$-deoxynucleosides could substitute for $2^{\prime}$-deoxycytidine, because of their close structural similarity to $2^{\prime}$-deoxycytidine. $2^{\prime}$-Deoxycytidine nucleotides contain mono-, di-, or triphosphate groups, and it is the triphosphate form that is the substrate for DNA

Table 1. Effect of 2'-deoxycytidine on the survival of ciliary and DRG neurons in vitro

\begin{tabular}{lcc} 
& \multicolumn{2}{l}{ Neurons/well } \\
\cline { 2 - 3 } Agent & \multicolumn{1}{c}{ Ciliary } & DRG \\
\hline None & $49 \pm 16$ & $339 \pm 32$ \\
$2^{\prime}$-Deoxycytidine & $39 \pm 7$ & $230 \pm 20$ \\
NGF & N.D. & $1738 \pm 61$ \\
Pig lung NTF & $2430 \pm 170$ & N.D.
\end{tabular}

Dissociated E8 chicken ciliary or DRG neurons were incubated for $4 \mathrm{~d}$ with 2 ' deoxycytidine $\left(10^{-3} \mathrm{M}\right), 2.5 \mathrm{~S}$ mouse $\mathrm{NGF}(100 \mathrm{ng} / \mathrm{ml})$, or a $25,000 \times g$ supernatan fraction of pig lung $(1 \mathrm{mg} / \mathrm{ml})$. The neurons were then fixed in glutaraldehyde and counted. 2.2 ganglion equivalents of ciliary neurons and 2.25 ganglion equivalents of DRG neurons were plated per well. Values represent the means \pm SE of 4 replicates. N.D. = not determined in this experiment. NGF has been previously shown not to be survival-promoting for ciliary neurons and the pig lung neurotrophic factor (NTF) has been previously shown not to be survival-promoting for DRG neurons (Wallace and Johnson, 1986, 1987). polymerase (Lehninger, 1982). Cytidine and cytosine are normally precursors in the formation of $2^{\prime}$-deoxycytidine; cytidine differs from $2^{\prime}$-deoxycytidine by having a hydroxyl group at position 2 in the ribose ring, and cytosine differs from $2^{\prime}$-deoxycytidine by not having the ribose ring (Lehninger, 1982). The other 2 -deoxynucleosides differ from 2 '-deoxycytidine by having a purine ring $\left(2^{\prime}\right.$-deoxyadenosine and $2^{\prime}$-deoxyguanosine) instead of a pyrimidine ring or having a different pyrimidine ring ( 2 '-deoxythymine). E8 ciliary neurons were incubated with insulin $(50 \mathrm{mU} / \mathrm{ml})$, or DRG neurons of the same age were incubated with NGF $(10 \mathrm{ng} / \mathrm{ml})$, and ARA C $\left(10^{-4} \mathrm{M}\right)$ was added to both neuronal types for $4 \mathrm{~d}$ in the presence of the various agents present at an equimolar concentration $\left(10^{-4} \mathrm{M}\right)$. The results showed that not only $2^{\prime}$-deoxycytidine, but also its nucleotides, blocked the cytotoxic effect of $10^{-4} \mathrm{M}$ ARA C on DRG neurons (Fig. 4), whereas the other 2'-deoxynucleosides, cytosine, or cytidine could not. Virtually identical results were obtained with ciliary neurons (data not shown). It is possible that the $2^{\prime}$-deoxycytidine nucleotides were dephosphorylated to $2^{\prime}$ deoxycytidine or that $2^{\prime}$-deoxycytidine was phosphorylated to a 2 -deoxycytidine nucleotide.

\section{Ability of varying nucleoside concentrations to block $A R A$ $C$-induced death of DRG neurons}

The previous experiment demonstrated that an equimolar concentration $\left(10^{-4} \mathrm{M}\right)$ of either cytidine, $2^{\prime}$-deoxyadenosine, $2^{\prime}$ deoxyguanosine, or $2^{\prime}$-deoxythymine could not block DRG neuron death caused by an equimolar concentration $\left(10^{-4} \mathrm{M}\right)$ of ARA C. An experiment was next performed to determine if any of those chemicals could block ARA C-induced neuron death when they were given in concentrations 10 - to 100-fold higher than ARA C. In this experiment all neurons were incubated with $10 \mathrm{ng} \mathrm{NGF} / \mathrm{ml}$. ARA C, $10^{-5} \mathrm{M}$, was given to inhibit survival, and varying concentrations of $2^{\prime}$-deoxycytidine, cytidine, or other $2^{\prime}$-deoxynucleosides were added to determine if they would block ARA C. The results of this experiment (Fig. 5) showed that high concentrations of cytidine could block ARA $\mathrm{C}$, but that high concentrations of $2^{\prime}$-deoxynucleosides other than $2^{\prime}$-deoxycytidine could not. The $\mathrm{EC}_{50}$ s were $2.5 \times 10^{-6} \mathrm{M}$ for $2^{\prime}$-deoxycytidine and $1 \times 10^{-4} \mathrm{M}$ for cytidine, whereas $10^{-3}$ $\mathrm{M}$ of either $2^{\prime}$-deoxyadenosine, $2^{\prime}$-deoxyguanosine, or $2^{\prime}$-deoxy- 


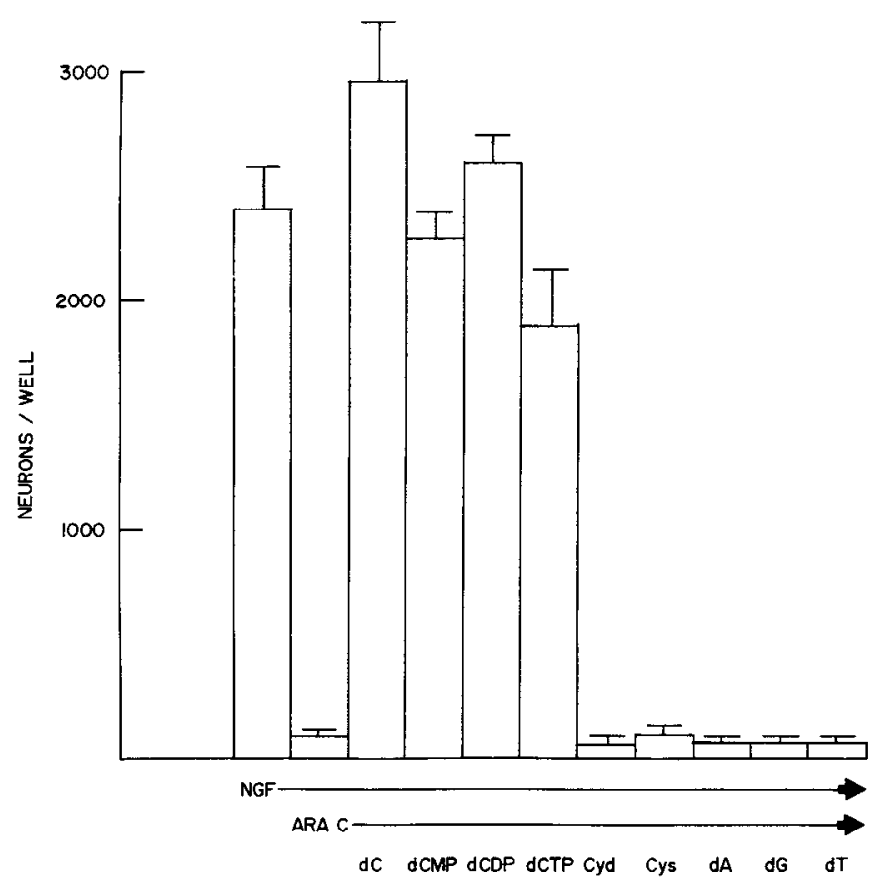

Figure 4. Ability of 2'-deoxycytidine and its nucleotides-cytidine, cytosine, or other $2^{\prime}$-deoxynucleosides-to block the cytotoxic effect of ARA C on DRG neurons. Dissociated E8 chicken DRG neurons were incubated for $4 \mathrm{~d}$ with $10 \mathrm{ng} / \mathrm{ml}$ of $2.5 \mathrm{~S}$ NGF alone (NGF) or $10 \mathrm{ng} /$ $\mathrm{ml}$ of 2.5S NGF and $10^{-4} \mathrm{M}$ ARA $\mathrm{C}$ in the absence or presence of $10^{-4}$ M $2^{\prime}$-deoxycytidine $(d C), 2^{\prime}$-deoxycytidine $5^{\prime}$-monophosphate $(d C M P)$, 2 -deoxycytidine $5^{\prime}$-diphosphate $(d C D P), 2^{\prime}$-deoxycytidine 5 '-triphosphate $(d C T P)$, cytidine $(C y d)$, cytosine $(C y s), 2^{\prime}$-deoxyadenosine $(d A)$, $2^{\prime}$-deoxyguanosine $(d G)$, or $2^{\prime}$-deoxythymine $(d T)$. The neurons were then fixed in glutaraldehyde and counted. 1.47 ganglion equivalents were plated per well. There was no survival in the absence of NGF. Values represent mcans \pm SE of 4 replicates.

thymine could not block ARA C $\left(10^{-5} \mathrm{M}\right)$. This indicates that $2^{\prime}$-deoxycytidine was about 40 -fold more potent than cytidine, but it is possible that cytidine was converted to $2^{\prime}$-deoxycytidine for it to be effective. In fact, ribonucleotides (i.e., CDP) are normally the precursors of deoxyribonucleotides (i.e., dCDP) in other cell types (Lehninger, 1982). These results suggest that the mechanism by which ARA $\mathrm{C}$ inhibits neuronal survival is through a process that preferentially utilizes $2^{\prime}$-deoxycytidine. The different $\mathrm{EC}_{50} \mathrm{~s}$ for 2 -deoxycytidine (Fig. 5) and ARA C (Figs. 2 and 3) may be the result of different amounts of membrane transport, metabolism, affinity for intracellular 2 '-deoxycytidine-dependent pathways, or possibly phosphorylation.

\section{Effect of antimitotic agents on the survival of parasympathetic and $D R G$ neurons}

A number of antimitotic agents which act by inhibiting DNA synthesis but whose mechanism of action does not involve competition with $2^{\prime}$-deoxycytidine were examined for their possible cytotoxic effect on ciliary and DRG neurons. These agents included adenine arabinoside (ARA A), thymine arabinoside (ARA T), 5-fluorodeoxyuridine + uridine (FUDR), and aphidicolin. ARA A, ARA T, and FUDR act by interfering with the incorporation of 2 '-deoxynucleotide into DNA, whereas aphidicolin is an inhibitor of DNA polymerase $\alpha$ (Huberman, 1981). Also, 5-bromodeoxycytidine and 5-azadeoxycytidine, which both cause hypomethylation of cylosine groups of DNA (Pinedo and Chabner, 1985), were tried. ARA C was used as the control. E8

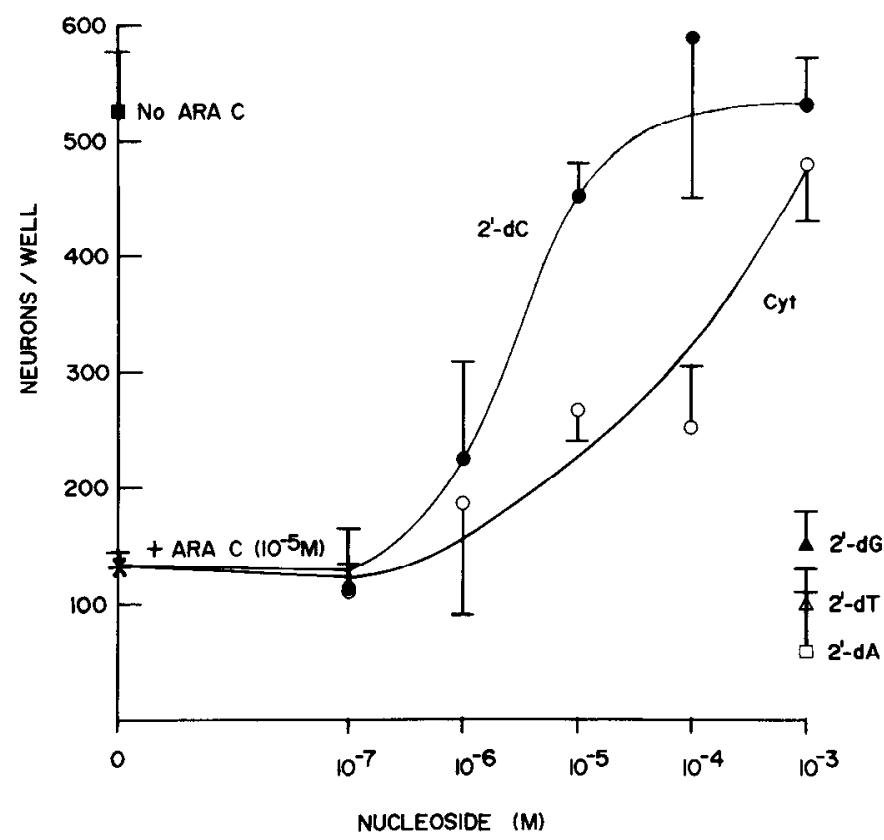

Figure 5. Ability of varying nucleoside concentrations to block ARA $\mathrm{C}$-induced death of DRG neurons. Dissociated E8 chicken DRG neurons were incubated for $4 \mathrm{~d}$ with $10 \mathrm{ng} \mathrm{NGF} / \mathrm{ml}$ in the absence of ARA $\mathrm{C}(\mathrm{D})$, in the presence of ARA C $\left(10^{-5} \mathrm{M}\right)(*)$, or in the presence of ARA $\mathrm{C}\left(10^{-5} \mathrm{M}\right)$ plus $2^{\prime}$-deoxycytidine $(0)$, cytidine $(0), 2^{\prime}$-deoxyadenosine $(\square), 2^{\prime}$-deoxyguanosine $(\boldsymbol{\Delta})$, or $2^{\prime}$-deoxythymine $(\Delta)$. The neurons were then fixed in glutaraldehyde and counted. Concentrations of 2 -deoxyadenosine, $2^{\prime}$-deoxyguanosine, and $2^{\prime}$-deoxythymine lower than $10^{-5}$ $M$ were also ineffective in blocking ARA C (data points not shown). 2.0 ganglion equivalents of DRG neurons were plated per well. Values represent means $\pm S E$ of 3 replicates.

ciliary neurons were incubated with insulin $(50 \mathrm{mU} / \mathrm{ml})$, and E8 DRG neurons were incubated with NGF $(10 \mathrm{ng} / \mathrm{ml})$ for 4 $\mathrm{d}$ in the presence of various antimitotics present at $10^{-4} \mathrm{M}$ and were then evaluated for survival as described. The results showed that no inhibitor of DNA synthesis other than ARA C had a cytotoxic effect on DRG neurons (Fig. 6). Identical results were obtained with ciliary neurons (data not shown). Thus, other antimitotic agents, present at a 5000-fold greater concentration $\left(1 \times 10^{-4} \mathrm{M}\right)$ than the $\mathrm{IC}_{50}$ of ARA C $\left(2 \times 10^{-8} \mathrm{M}\right.$; Figs. 2 and 3) were not cytotoxic.

\section{Effect of a deoxynucleoside membrane transport inhibitor, nitrobenzylthioinosine, on the cytotoxic effect of $A R A C$}

Nucleosides, deoxynucleosides, and ARA $C$ gain access to the interior of cells by nonconcentrative, reversible facilitated diffusion through a membrane transporter that has been characterized in a number of cell types (Plagemann et al., 1978; Wiley et al., 1982; Young and Jarvis, 1983), although not in neurons. Nitrobenzylthioinosine (NBTl) is a specific inhibitor of transport of these compounds (Wiley et al., 1982; Young and Jarvis, 1983 ) into cells. The possibility that ARA $C$ was gaining intracellular access to ciliary and DRG neurons via this transporter was examined by determining if NBTI could block the cytotoxic effect of ARA C. E8 ciliary or DRG neurons were incubated with insulin $(50 \mathrm{mU} / \mathrm{ml})$ or $\mathrm{NGF}(10 \mathrm{ng} / \mathrm{ml})$, respectively, and either NBTI alone $\left(10^{-4} \mathrm{M}\right)$ or NBTI + ARA C $\left(10^{-4} \mathrm{M}\right)$ for 4 $\mathrm{d}$ and then evaluated for survival. The results showed that NBTI blocked the cylotoxic effect of ARA C on DRG (Fig. 6) neurons. Similar results were obtained with ciliary neurons (data not 


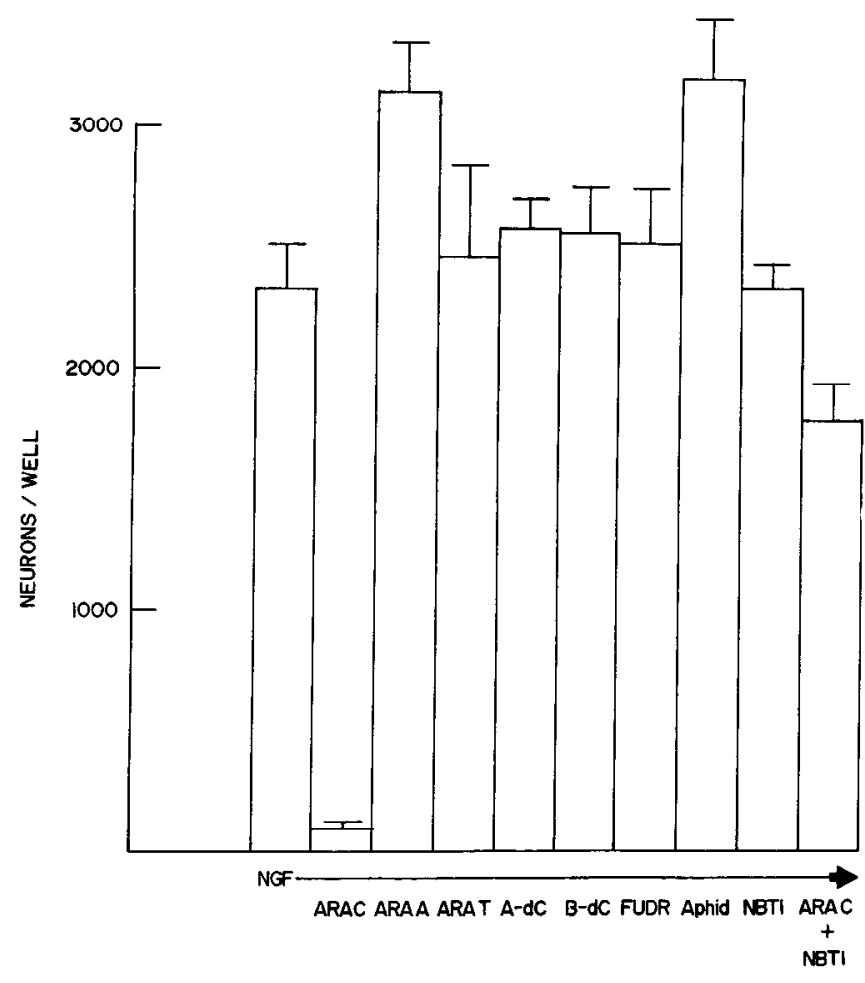

Figure 6. Effect of antimitotic agents on the survival of DRG neurons. Dissociated E8 chicken DRG neurons were incubated for $4 \mathrm{~d}$ with $10 \mathrm{ng} / \mathrm{ml}$ of $2.5 \mathrm{~S}$ NGF in the absence (NGF) or presence of $10^{-4} \mathrm{M} A R A$ $C$, adenine arabinoside ( $A R A A)$, thymine arabinoside ( $A R A T)$, 5 -azadeoxycytidine $(A-d C), 5$-bromodeoxycytidine $(B-d C)$, 5-fluorodeoxyuridine + uridine $(F U D R)$, aphidicolin (Aphid), nitrobenzylthioinosine $(N B T I)$, or ARA C + NBTI. 1.47 ganglion equivalents of neurons were plated per well. Values represent means \pm SE of 4 replicates.

shown). This suggests that ARA C enters the neuron via a NBTIsensitive membrane transporter such as those that have been found in other cell types. This experiment also showed that NBTI, by itself, was not toxic to the neurons.

\section{Effect of NGF on ARA C-induced inhibition of DRG neuron survival}

Previous experiments demonstrated the inhibition by ARA C of DRG neuron survival in the presence of one concentration of NGF $(10 \mathrm{ng} / \mathrm{ml})$. An experiment was performed to determine the concentration dependence of the survival-promoting effect of varying concentrations of NGF in the presence of one concentration of ARA C. E8 DRG neurons were incubated with no NGF or $1,10,100$, or $1000 \mathrm{ng} / \mathrm{ml} \mathrm{NGF}$ in the absence or presence of $10^{-6}$ or $10^{-5} \mathrm{M}$ ARA C for $4 \mathrm{~d}$ and then evaluated for survival. The results showed that ARA $C$ was cytotoxic at all concentrations of NGF (Fig.7). High concentrations of NGF could not completely overcome the cytotoxic effects of ARA C, suggesting that NGF and ARA $C$ were not directly competing with each other. This demonstrates that ARA C decreases the efficacy of NGF and, thus, that it is functionally a noncompetitive antagonist since increasing NGF concentrations only partially overcame the effects of ARA C. These results contrast with those demonstrating that ARA $\mathrm{C}$ is a competitive antagonist of 2'-deoxycytidine (Fig. 5) since 2'-deoxycytidine can completely overcome the cytotoxic effects of ARA C.

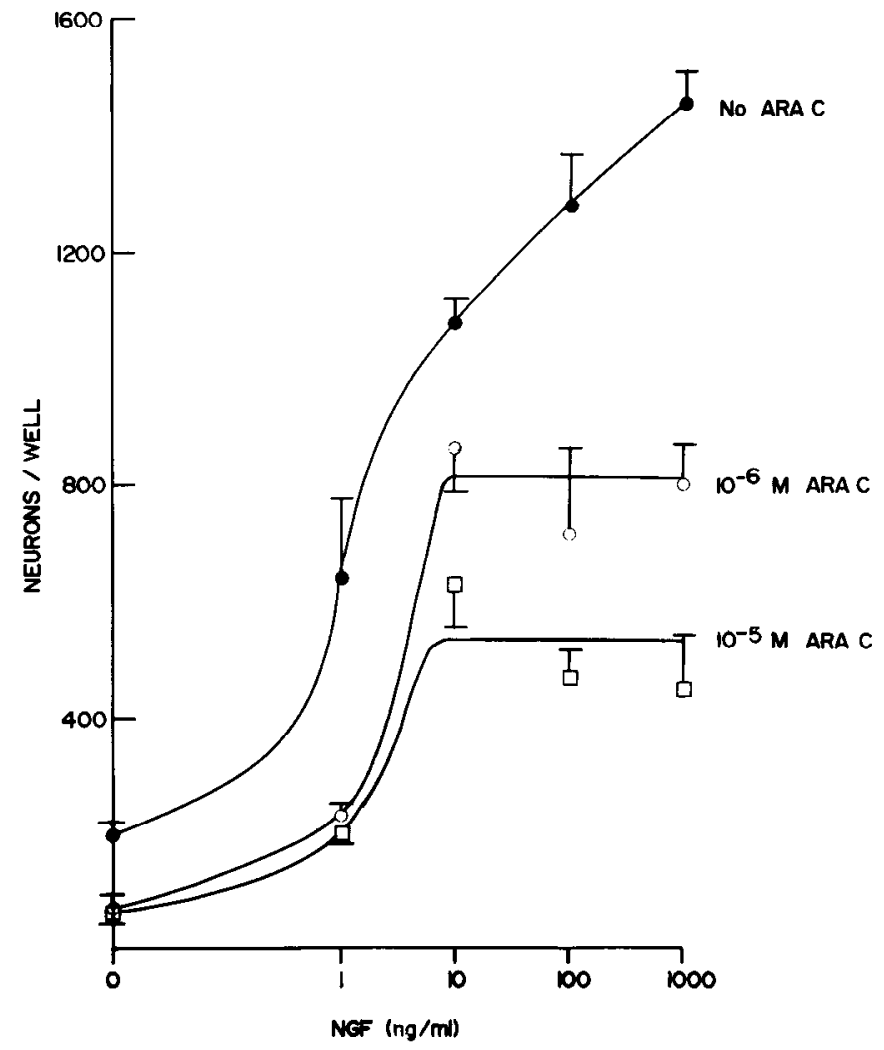

Figure 7. Effect of NGF on ARA C-induced inhibition of DRG neuron survival. Dissociated E8 chicken DRG neurons were incubated for $4 \mathrm{~d}$ with varying concentrations of $2.5 \mathrm{~S}$ NGF prepared in $0.1 \% \mathrm{BSA}$ in the absence $(\bullet)$ or presence of $10^{-6} \mathrm{M}$ ARA C (O) or $10^{-3} \mathrm{M}$ ARA C ( $\square$ ). 1.33 ganglion equivalents of neurons were plated per well. Values represent means $\pm \mathrm{SE}$ of 3 replicates.

\section{Discussion}

ARA $C$ is an antimitotic and cancer chemotherapeutic drug that is a structural analog and competitive inhibitor of 2'-deoxycytidine in cells capable of mitosis. In the experiments presented in this paper, it was found to inhibit in a concentration-dependent manner the survival of postmitotic parasympathetic and DRG neurons in vitro. Several other studies have reported that ARA C is toxic to neurons in vitro (Bustos et al., 1980; Oorschot and Jones, 1986; Smith and Orr, 1987). However, the greater implication that $2^{\prime}$-deoxycytidine may have an important role in neuronal survival has not been previously considered. It is probable that this cytotoxic effect of ARA C on neurons was not the result of a general toxic effect, such as membrane perturbation, for a number of reasons. Under the culture conditions used here, the cytotoxic effect of ARA C on neurons was potent, with an $\mathrm{IC}_{50}=2 \times 10^{-8} \mathrm{M}$ on both neuronal types and could be blocked by $2^{\prime}$-deoxycytidine and its deoxynucleotides, but not by a number of structurally related compounds that included cytosine, or other 2'-deoxynucleosides. An important experiment ruled out the possibility that 2 -deoxycytidine might be blocking the toxic effect of ARA C on neurons by stimulating the few non-neuronal cells that were present: When $2^{\prime}$-deoxycytidine was added to cultures containing neurons and nonneuronals (but no trophic agent or ARA C), there was no increase in survival compared with cultures without 2 -deoxycytidine, 
trophic agent, or ARA C. Thus, it is unlikely that $2^{\prime}$-deoxycytidine indirectly blocks the cytotoxic effect of ARA C on neurons by stimulating non-neuronals to condition the medium, i.e., to make neurotrophic factors.

The blockade by 2'-deoxycytidine of ARA C-induced neuronal death could be taking place at several sites. 2'-Deoxycytidine may block ARA $C$ at an intracellular site, one involved in the regulation of neuronal survival. Alternatively, $2^{\prime}$-deoxycytidine may block ARA $C$ at a membrane transporter that is specific for $2^{\prime}$-deoxycytidine and ARA C, one that is not blocked by at least a 100 -fold higher concentration of other $2^{\prime}$-deoxynucleosides. However, it is generally considered, at least in other cell types (neurons have not been examined), that there is not a specific transporter for 2'-deoxycytidine and ARA C, but rather that there is one common transporter with low specificity for all nucleosides and deoxynucleosides (Cohen et al., 1979; Paterson et al., 1979). The ability of NBTI to prevent ARA $\mathrm{C}$ toxicity indicates that neurons accumulate deoxynucleosides in a manner similar to other cell types. Last, $2^{\prime}$-deoxycytidine may block ARA $\mathrm{C}$ by competing with it for intracellular phosphorylation (Balzarini et al., 1987).

As mentioned above, ARA $\mathrm{C}$ neurotoxicity was blocked in these neurons by a specific inhibitor of the nucleoside membrane transporter, nitrobenzylthioinosine. This indicates that ARA C needed to gain access intracellularly for it to be effective. On the other hand, it was found that NBTI by itself was not toxic to the neurons. This suggests that, if 2 '-deoxycytidine is important for neuronal survival, the source of the 2 '-deoxycytidine was not the culture medium, since NBTI would normally be expected to block the membrane transport of 2'-deoxycytidine from the medium into the neurons. This implies that neurons may synthesize 2 -deoxycytidine intracellularly, as do other cell types.

Other antimitotic agents with structural similarity-including ARA A, ARA T, FUDR, A-dC, and B-dC-were not cytotoxic to the neurons. In addition, an antimitotic agent that is not structurally related to ARA C, aphidicolin, was not cytotoxic. These findings indicate that inhibition of DNA synthesis or repair was not the mechanism by which ARA $C$ inhibited neuronal survival since these other agents are DNA synthesis and/ or repair inhibitors (Friedberg, 1985) yet had no effect on neuronal survival. They also suggest that other $2^{\prime}$-deoxynucleosides, including 2'-deoxyadenosine or 2'-deoxythymine, are not critical for neuronal survival, since there was no inhibition of survival by ARA A, ARA T, or FUDR. Further, they show that the ability of ARA $C$ to kill the neurons was not due to a toxic effcct of the arabinoside ring, since both ARA A and ARA T also contain arabinoside but were without any effect on neuronal survival. Last, the results show that a change in the cytosine ring, as in 5-bromodeoxycytidine and 5-azadeoxycytidine, as opposed to an alteration of the ribose ring, as in ARA C, was not sufficient to allow these agents to be cytotoxic. This provides further evidence for the specificity of the adverse effects of ARA $C$ on neuronal survival. Thus, these data very strongly suggest that ARA $C$ inhibits survival of parasympathetic and DRG neurons by interfering with an intracellular $2^{\prime}$-deoxycytidinespecific process that is independent of DNA synthesis or repair.

Whereas ARA C inhibited neuronal survival by a mechanism that was reversible by $2^{\prime}$-deoxycytidine, $2^{\prime}$-deoxycytidine by itself in the absence of trophic factor (i.e., NGF) under these culture conditions was not a survival-promoting factor. One possible explanation for this is that $2^{\prime}$-deoxycytidine may be necessary but not sufficient for neuronal survival. Survival may be dependent simultaneously on several critical intracellular molecules, one of which may be 2'-deoxycytidine.

ARA C killed neurons that could normally be maintained in vitro by several different trophic factors. Both $\mathrm{KCl}$ - and insulinstimulated survival of parasympathetic neurons and NGF-stimulated survival of DRG neurons were inhibited by ARA C. Inhibition of survival was seen not only if the neurons were plated in ARA C, but also if ARA C was added after the neurons had become established in culture for a week (data not shown). It has also been found that ARA $C$ can inhibit survival of ciliary neurons whose survival could normally be maintained in vitro by a parasympathetic factor from pig lung (Wallace and Johnson, 1986, 1987) and survival of rat sympathetic neurons normally maintained by NGF (data not shown). This suggests that a 2'-deoxycytidine-dependent process may be a common mediator of the survival-promoting effects of several trophic factors on peripheral neurons or that $2^{\prime}$-deoxycytidine takes part in a general survival pathway common to these neurons but one that may not be directly linked to trophic factor action. Then, one may speculate that alteration of levels of $2^{\prime}$-deoxycytidine could conceivably be a faclor in neuronal death in vivo.

ARA $C$ is used clinically as a cancer chemotherapeutic drug to treat leukemia. Notable among its side effects is CNS toxicity, which has been seen mostly as cerebral and cerebellar damage (Lazarus et al., 1981; Winkelman and Hines, 1983; Benger et al., 1985; Hwang et al., 1985). The incidence of cerebellar toxicity has been shown to increase with the dose of ARA C and the age of the patient (Herzig et al., 1987a, b). Postmortem examination has revealed loss of Purkinje cells (Winkelman and Hines, 1983). Peripheral sensory neuropathy, seen as parasthesis, has also been reported in a small number of patients (Russell and Powles, 1974; Scherokman et al., 1985). Autonomic dysfunction has not been reported, but it is possible that such changes would be subtle compared with the more prominent side effects of ARA C, and the effects of cancer. Thus, based on these reports, there is some evidence to suggest that $2{ }^{\prime}$-deoxycytidine may also have an important role in the survival of certain neurons in vivo.

Interestingly, another structurally related drug, 2', 3'-dideoxycytidine, has also been shown to cause neurotoxicity. 2',3'-Dideoxycytidine has been shown to be the most potent agent in the class of nucleoside analogs for inhibition of the cytopathic effect of the human immunodeficiency virus (HIV), the etiologic agent of acquired immunodeficiency syndrome (AIDS) (Mitsuya et al., 1987). Phase I clinical trials have reported that $2^{\prime}, 3^{\prime}$ dideoxycytidine caused a peripheral sensory neuropathy in $50 \%$ of treated patients and that it appeared to be dose dependent and due to axonal degeneration (Yarchaon et al., 1988). Preliminary experiments in our laboratory have shown that $2^{\prime}, 3^{\prime}$-dideoxycytidine kills dorsal root sensory neurons in vitro and that this could be blocked by 2 -deoxycytidine (T. L. Wallace, unpublished observations). We are currently carrying out a full characterization of this in vitro obscrvation, which may help explain the clinical neuropathic effects of this AIDS drug.

There are at least 3 possible ways in which ARA $C$ could inhibit the survival of neurons by blocking a $2^{\prime}$-deoxycytidinedependent specific pathway. These include (1) inhibition of DNA synthesis (Kufe and Major, 1982), (2) inhibition of DNA repair (Fram and Kufe, 1985), or (3) inhibition of a non-DNA, 2'-deoxycylidine-dependent process. Postmitotic neurons, which were used in this study, do not undergo DNA synthesis for cell 
replication. Therefore, the mechanism by which ARA C inhibits neuronal survival is not by inhibition of DNA synthesis. In fact, our work has shown that parasympathetic and DRG neurons are not sensitive to high concentrations of a number of inhibitors of DNA synthesis, except for ARA C. The possibility remains that the other antimitotics were not transported into the neurons, but such selective transport would be unlike any other cell type and would seem very unlikcly. In fact, we have previously shown that a much lower concentration $\left(10^{-5} \mathrm{M}\right)$ of aphidicolin completely inhibits viral DNA synthesis in neurons (Wilcox and Johnson, 1988), indicating that aphidicolin can get into the neuron. It is also possible that ARA C could inhibit neuronal survival by interfering with DNA repair since ARA C can inhibit DNA repair in other cell types (Fram and Kufe, 1985; Friedberg, 1985). However, it would again be difficult to explain why the other antimitotics tested (i.e., aphidicolin) had no effect on survival. Aphidicolin has also been shown to inhibit DNA repair (Berger et al., 1979), yet did not inhibit neuronal survival.

There is some evidence that ARA C can alter other cellular functions. ARA $C$ has been shown to inhibit glycoprotein and glycolipid synthesis by blocking incorporation of galactose, $\mathrm{N}$-acetylglucosamine, and sialic acid from their nucleotide carriers in hamster embryo fibroblasts (Hawtrey et al., 1973, 1974). ARA $C$ inhibited de novo sialic acid synthesis and membrane resialylation in HL-60 leukemia cells (Hindenburg et al., 1985) and has been reported to be a competitive inhibitor of sialic acid synthetase (Myers-Robfogel and Spataro, 1980) and of sialyltransferase (Klohs et al., 1979; Myers-Robfogel and Spataro, 1980). Several other studies have suggested that the cytotoxic effect of ARA C may involve the activation of certain cellular systems. Cycloheximide, an inhibitor of protein synthesis, has been shown to protect against the cytotoxic effect of ARA C on intestinal epithelial (Lieberman et al., 1970) and bone marrow cells (Ben-Ishay and Farber, 1975) in vitro. This suggests that cell death due to ARA $C$ is not a process of mere passive attrition, but may require the active synthesis of specific proteins. We have recently tested this hypothesis using neonatal rat sympathetic neurons, and we found that RNA and protein synthesis inhibitors blocked ARA C-induced neuronal death (Wallace et al., 1988). This is similar to the finding that RNA and protein synthesis inhibitors also block death of sympathetic neurons due to NGF deprivation (Martin et al., 1988) and suggests that a similar "death program" may occur in both conditions.

A number of studies have also shown that ARA C in nonlethal concentrations can exert a variety of actions through differential alteration of gene expression. In human U-937 cells, it increases lcvcls of $c$-fos and decreases levels of $c$-myc but does not change the expression of actin or $c$-fms (Mitchell et al., 1986). In K562 cells, ARA C causes increased heme synthesis, accumulation of $\alpha, \gamma, \epsilon$, and $\zeta$-globin RNA, and enhanced cell surface expression of glycophorin (Watanabe et al., 1985). In the embryonic chick retina, ARA C increases the levels of glutamine synthetase (Ones and Moscona, 1974). Last, it has also been reported that ARA $C$ can cause the differentiation of cells (Griffin et al., 1982; Takeda et al., 1982). Thus, ARA C may have a complex effect on cellular function. It is probable that ARA C exerts many of these effects by competing with $2^{\prime}$-deoxycytidine for incorporation in to DNA, but it is also possible, based on work presented in this paper, that ARA C could be exerting some of its actions by competing with 2 '-deoxycytidine at other sites.

Interestingly, it has been shown that 2 pools of dCTP exist in cells capable of mitosis (Mordoh and Fridlender, 1977; Ni- cander and Reichard, 1985), suggesting that it can be utilized in several different ways. One dCTP pool is used preferentially for DNA synthesis (Spyrou and Reichard, 1987), whereas the other is used for synthesis of deoxycytidine adducts, such as dCDP-diglyceride (Ter Schegget et al., 1971), dCMP-phosphatidic acid (Medrano and Mordoh, 1979), and dCDP-choline and dCDP-ethanolamine (Sugino, 1957; Potter and Buettner-Janusch, 1958; Spyrou and Rcichard, 1987). These deoxycytidine adducts have been found to substitute effectively for cytidine adducts (Lehninger, 1982) as intermediates in the formation of phospholipids (Kennedy et al., 1959; Ter Schegget et al., 1971). Substitution of a false substrate, such as ARA C, for $2^{\prime}$-deoxycytidine may block this pathway. ARA $C$ has been shown to inhibit the formation of phosphatidyl-dCMP in mouse thyImocytes (Iujvidin et al., 1983). ARA C has also been shown to form ARA C diphosphate choline in normal and neoplastic cells (Lauzon et al., 1978a, b). We speculate that the formation of deoxyliponucleotides in postmitotic neurons may be critical for neuronal survival and that ARA $\mathrm{C}$ acts to inhibit neuronal survival by competing with $2^{\prime}$-deoxycytidine in this synthetic pathway.

\section{References}

Acheson, A., W. Vogl, W. B. Huttner, and H. Thoenen (1986) Methyltransferase inhibitors block NGF-regulated survival and protein phosphorylation in sympathetic neurons. Eur. Mol. Biol. Org. J. 5: 2799-2803.

Balzarini, J., D. A. Cooney, M. Dalal, G.-J. Kang, J. E. Cupp, E. De Clercq, S. Broder, and D. G. Johns (1987) 2',3'-Didenxycytidine: Regulation of its metabolism and anti-retroviral potency by natural pyrimidine nucleosides and by inhibitors of pyrimidine nucleotide synthesis. Mol. Pharmacol. 32: 798-806.

Barbin, G., M. Manthorpe, and S. Varon (1984) Purification of the chick eye ciliary neuronotrophic factor. J. Neurochem. 43: 14681478.

Barde, Y. A., D. Edgar, and H. Thoenen (1982) Purification of a new neurotrophic factor from mammalian brain. Eur. Mol. Biol. Org. J. 1: 549-553.

Benger, A., G. P. Browman, I. R. Walker, and H. D. Preisler (1985) Clinical evidence of a cumulative effect of high-dose cytarabine on the cerebellum in patients with acute leukemia: A leukemia intergroup report. Cancer Treat. Rep. 69: 240-241.

Ben-Ishay, Z., and E. Farber (1975) Protective effects of an inhibitor of protein synthesis, cycloheximide, on bone marrow damage induced by cytosine arabinoside or nitrogen mustard. Lab. Invest. 33: 478490.

Berger, N. A., K. K. Kurohara, S. J. Petzold, and G. W. Sikorski (1979) Aphidicolin inhibits eukaryotic DNA replication and repair-Implications for involvement of DNA polymerase $\alpha$ in both processes. Biochem. Biophys. Res. Commun. 89: 218-225.

Bocchini, V., and P. U. Angeletti (1969) The nerve growth factor: Purification as a 30,000-molecular weight protein. Proc. Natl. Acad. Sci. USA 64: 787-794.

Bottenstein, J. E., S. D. Skaper, S. S. Varon, and G. H. Sato (1980) Selective survival of neurons from chick embryo sensory ganglionic dissociates utilizing serum-free supplemented medium. Exp. Cell Res. 125: 183-190.

Bustos, M., F. J. Alcain, and F. Padilla (1980) Survival of chick embryo ciliary ganglia neurons in cellular cultures. Collagen, polylysine and cytosine-arabinoside effects. Trab. Inst. Cajal 71: 63-70.

Cohen, A., B. Ullman, and D. W. Martin, Jr. (1979) Characterization of a mutant mouse lymphoma cell with deficient transport of purine and pyrimidine nucleosides. J. Biol. Chem. 254: 112-116.

Collins, F., and A. Dawson (1983) . An effect of nerve growth factor on parasympathetic neurite outgrowth. Proc. Natl. Acad. Sci. USA 80: 2091-2094.

Danhauser, L. L., and Y. M. Rustum (1980) Effect of thymidine on the toxicity, antitumor activity, and metabolism of $1-\beta$-D-arabinofurar.osylcytosine in rats bearing a chemically induced colon carcinoma. Cancer Res. 40: 1274-1280. 
Fram, R. J., and D. W. Kufe (1985) Inhibition of DNA excision repair and the repair of $x$-ray-induced DNA damage by cytosine arabinoside and hydroxyurea. Pharmacol. Ther. 31: 165-176.

Friedberg, E. C. (1985) In DNA repair, Freeman, New York.

Griffin, J., D. Munroe, P. Major, and D. Kufe (1982) Induction of differentiation of human myeloid leukemic cells by inhibitors of DNA synthesis. Exp. Hematol. (Copenh.) 10: 744-781.

Hagag, N., S. Halegoua, and M. Viola (1986) Inhibiton of growth factor-induced differentiation of PC12 cells by microinjection of antibody to ras p21. Nature 319: 680-682.

Hawtrey, A. O., T. Scott-Burden, P. Jones, and G. Robertson (1973) Inhibition by 1-beta-D-arabinofuranosylcytosine of the incorporation of $\mathrm{N}$-acetylneuraminic acid into glycolipids and glycoproteins of hamster embryo cells. Biochem. Biophys. Res. Commun. 54: 1282-1287.

Hawtrey, A. O., T. Scott-Burden, and G. Robertson (1974) Inhibition of glycoprotein and glycolipid synthesis in hamster embryo cells by cytosine arabinoside and hydroxyurea. Nature 252: 58-60.

Hefti, F., J. Hartikka, F. Eckenstein, H. Gnahn, K. Heumann, and M. Schwab (1985) Nerve growth factor increases choline acetyltransferase but not survival or fiber outgrowth of cultured fetal septal cholinergic neurons. Neuroscience 14: 55-68.

Herzig, R. H., G. P. Herzig, S. N. Wolff, J. D. Hines, J. W. Fay, and G. L. Phillips (1987a) Central nervous system effects of high-dose cytosine arabinoside. Semin. Oncol. (Suppl. 1) 14: 21-24.

Herzig, R. H., J. D. Hines, G. P. Herzig, S. N. Wolff, P. A. Cassileth, H. M. Lazarus, D. J. Adelstein, R. A. Brown, P. F. Coccia, S. Strandjord, J. J. Mazza, J. Fay, and G. L. Phillips (1987b) Cerebellar toxicity with high-dose cytosine arabinoside. J. Clin. Oncol. 5: 927932.

Hindenburg, A. A., R. N. Taub, S. Grant, G. Chang, and M. A. Baker (1985) Effects of pyrimidine antagonists on sialic acid regeneration in HL-60 cells. Cancer Res. 45: 3048-3052.

Huberman, J. A. (1981) New views of the biochemistry of eucaryotic DNA replication revealed by aphidicolin, an unusual inhibitor of DNA polymerase alpha. Cell 23: 647-648.

Hwang, T.-L., W. K. A. Yung, E. H. Estey, and W. S. Fields (1985) Central nervous system toxicity with high dose Ara-C. Neurology 35 : $1475-1479$

Iujvidin, S., C. Feledi, E. E. Medrano, and J. Mordoh (1983) Inhibitory effect of 1-beta-D-arabinofuranosylcytosine on the synthesis of phosphatidyl-dCMP. Eur. J. Biochem. 130: 293-296.

Johnson, E. M., P. D. Gorin, L. D. Brandeis, and J. Pearson (1980) Dorsal root ganglion neurons are destroyed by exposure in utero to maternal antibody to nerve growth factor. Science 210:916-918.

Kennedy, E. P., L. F. Borkenhagen, and S. W. Smith (1959) Possible metabolic functions of deoxycytidine diphosphate choline and deoxycytidine diphosphate ethanolamine. J. Biol. Chem. 234: 19982000 .

Klohs, W. D., R. J. Bernacki, and R. Korytnyk (1979) Effects of nucleotides and nucleotide analogues on human serum sialyltransferase. Cancer Res. 39: 1231-1238.

Kufe, D. W., and P. P. Major (1982) Studies on the mechanism of action of cytosine arabinoside. Med. Pediatr. Oncol. 1: 49-67.

Lauzon, G. J., J. H. Paran, and A. R. P. Paterson (1978a) Formation of $1-\beta$-D-arabinofuranosylcytosine diphosphate choline in cultured human leukemic RPMI 6410 cells. Cancer Res. 38: 1723-1729.

Lauzon, G. J., A. R. P. Paterson, and A. W. Belch (1978b) Formation of $1-\beta$-D-arabinofuranosylcytosine diphosphate choline in neoplastic and normal cells. Cancer Res. 38: 1730-1733.

Lazarus, H. M., R. H. Herzig, G. P. Herzig, G. L. Phillips, U. Roessmann, and D. J. Fishman (1981) Central nervous system toxicity of high-dose systemic cytosine arabinoside. Cancer 48: 2577-2582.

Lehninger, A. L. (1982) In Principles of Biochemistry, Worth, New York.

Levi-Montalcini, R., and P. U. Angeletti (1968) Nerve growth factor. Physiol. Rev. 48: 534-569.

Lieberman, M. W., R. S. Verbin, M. Landay, H. Liang, E. Farber, T. N. Lee, and R. Starr (1970) A probable role for protein synthesis in intestinal epithelial cell damage induced in vivo by cytosine arabinoside, nitrogen mustard, or x-irradiaiton. Cancer Res. 30: 942 951.

Martin, D. P., R. E. Schmidt, P. S. DiStefano, O. H. Lowry, J. G. Carter, and E. M. Johnson, Jr. (1988) Inhibitors of protein synthesis and RNA synthesis prevent neuronal death caused by nerve growth factor deprivation. J. Cell Biol. 106: 829-844.
Medrano, E., and J. Mordoh (1979) Synthesis of phosphatidyl-dCMP in permeabilized normal human lymphocytes. Mol. Cell. Biochem. 24: $159-165$.

Mitchell, T., E. Sariban, and D. Kufe (1986) Effects of 1- $\beta$-D-arabinofuranosylcytosine on proto-oncogene expression in human U-937 cells. Mol. Pharmacol. 30: 398-402.

Mitsuya, H., R. F. Jarrett, M. Matsukura, F. D. M. Veronese, A. L. DeVico, M. G. Sarngadharan, D. G. Johns, M. S. Reitz, and S. Broder (1987) I ong-term inhibition of human T-lymphotropic virus type III/lymphadenopathy-associated virus (human immunodeficiency virus) DNA synthesis and RNA expression in T cells protected by $2^{\prime}, 3^{\prime}$-dideoxynucleosides in vitro. Proc. Natl. Acad. Sci. USA 84: 20332037.

Montz, H. P. M., G. E. Davis, S. D. Skaper, M. Manthorpe, and S. Varon (1985) Tumor-promoting phorbol diester mimics two distinct neuronotrophic factors. Dev. Brain Res. 23: 150-154.

Mordoh, J., and B. Fridlender (1977) Synthesis of a compound soluble in organic solvents from deoxycytidine triphosphate in permeabilized normal human lymphocytes. Mol. Cell. Biochem. 16: 177-185.

Morrison, R. S., A. Sharma, J. de Vellis, and R. A. Bradshaw (1986) Basic fibroblast growth factor supports the survival of cerebral cortical neurons in primary culture. Proc. Natl. Acad. Sci. USA 83: 75377541

Myers-Robfogel, M. W., and A. C. Spataro (1980) 1- $\beta$-D-Arabinofuranosylcytosine nucleotide inhibition of sialic acid metabolism in W-138 cells. Cancer Res. 40: 1940-1943.

Nicander, B., and P. Reichard (1985) Relations between synthesis of deoxyribonucleotides and DNA replication in 3 T6 fibroblasts. J. Biol. Chem. 260: 5376-5381.

Nishi, R., and D. K. Berg (1981) Effects of high $\mathrm{K}^{+}$concentrations on the growth and development of ciliary ganglion neurons in cell culture. Dev. Biol. 87: 301-307.

Ones, R. E., and A. A. Moscona (1974) Effects of cytosine arabinoside on differential gene expression in embryonic neural retina. J. Cell Biol. 61: 688-700.

Oorschot, D. E., and D. G. Jones (1986) Non-neuronal cell proliferation in tissue culture: Implications for axonal regeneration in the central nervous system. Brain Res. 368: 49-61.

Paterson, A. R. P., S.-E. Y. Yang, E. Y. Lau, and C. E. Cass (1979) Low specificity of the nucleoside transport mechanism of RPMI 6410 cells. Mol. Pharmacol. 16: 900-908.

Pinedo, H. M., and B. A. Chabner (1985) In Cancer Chemotherapy, Annual 7, Elsevier, New York.

Plagemann, P. G., R. Marz, and R. M. Wohlueter (1978) Transport and metabolism of deoxycytidine and 1-beta-D-arabinofuranosylcytosine into cultured Novikoff rat hepatoma cells, relationship to phosphorylation, and regulation of triphosphate synthesis. Cancer Res. 38: 978-989.

Potter, R. L., and V. Buettner-Janusch (1958) Deoxycytidine diphosphoethanolamine and its ribose analogue in the acid-soluble extract of calf thymus. J. Biol. Chem. 233: 462-465.

Rohrer, H., and H. Thoenen (1987) Relationship between differentiation and terminal mitosis: Chick sensory and ciliary neurons differentiate after terminal mitosis of precursor cells, whereas sympathetic neurons continue to divide after differentiation. J. Neurosci. 7 : 3739 3748.

Russell, J. A., and R. L. Powles (1974) Neuropathy due to cytosine arabinoside. Br. Med. J. 4: 652-653.

Rydel, R. E., and L. A. Greene (1988) cAMP analogs promote survival and neurite outgrowth in cultures of rat sympathetic and sensory neurons independently of nerve growth factor. Proc. Natl. Acad. Sci. USA 85: 1257-1261.

Scherokman, B., M. R. Filling-Katz, and D. Tell (1985) Brachial plexus neuropathy following high-dose cytarabine in acute monoblastic leukemia. Cancer Treat. Rep. 69: 1005-1006.

Skaper, S. S., I. Selak, M. Manthorpe, and S. Varon (1984) Chemically defined requirements for the survival of cultured 8-day chick embryo ciliary ganglion neurons. Brain Res. 302: 281-290.

Skaper, S., H. P. M. Montz, and S. Varon (1986) Control of $\mathrm{Na}^{+}, \mathrm{K}^{+}-$ pump activity in dorsal root ganglionic neurons by different neuronotrophic agents. Brain Res. 386: 130-135.

Smith, R. A., and D. J. Orr (1987) The survival of adult mouse sensory neurons in vitro is enhanced by natural and synthetic substrata, particularly fibronectin. J. Neurosci. Res. 17: 265-270.

Spyrou, G., and P. Reichard (1987) Compartmentation of dCTP pools. 
Evidence from deoxyliponucleotide synthesis. J. Biol. Chem. 262: $16425-16432$.

Sugino, Y. (1957) Deoxycytidine diphosphate choline, a new deoxyribosidic compound. J. Am. Chem. Sci. 79: 5072-5075.

Takeda, K., J. Minowada, and A. Block (1982) Kinetics of appearance of differentiation-associated characteristics in ML-1, a line of human myeloblastic leukemia cells, after treatment with 12-O-tetradecanoylphorbol-13-acetate, dimethyl sulfoxide, or 1-beta-D-arabinofuranosylcytosine. Cancer Res. 42: 5152-5158.

Ter Schegget, J., H. Van Den Bosch, M. A. Van Baak, K. Y. Hostetler, and P. Borst (1971) The synthesis and utilization of dCDP-diglyceride by a mitochondrial fraction from rat liver. Biochim. Biophys. Acta 239: 234-242.

Wallace, T. L., and E. M. Johnson (1986) Characterization of choline acetyltransferase-sustaining and survival-promoting activities for parasympathetic neurons in pig lung. Brain Res. 375: 92-101.

Wallace, T. L., and E. M. Johnson (1987) Partial purification of a parasympathetic neurotrophic factor from pig lung. Brain Res. 411: 351-363.

Wallace, T. L., D. P. Martin, and E. M Johnson, Jr. (1988) Neuronal death caused by cytosine arabinoside (ARA C) resembles death caused by nerve growth factor (NGF) deprivation. Soc. Neurosci. Abstr. 14: 1119.
Watanabe, T., T. Mitchell, E. Sariban, K. Sabbath, J. Griffin, and D. Kufe (1985) Effects of $1-\beta$-D-arabinofuranosylcytosine and phorbol ester on differentiation of human K562 erythroleukemia cells. Mol. Pharmacol. 27: 683-688.

Wilcox, C. L., and E. M. Johnson, Jr. (1988) Characterization of nerve growth factor-dependent herpes simplex virus latency in neurons in vitro. J. Virol. 62: 393-399.

Wiley, J. S., S. P. Jones, W. H. Sawyer, and A. R. P. Paterson (1982) Cytosine arabinoside influx and nucleoside transport sites in acute leukemia. J. Clin. Invest. 69: 479-489.

Winkelman, M. D., and J. D. Hines (1983) Cerebellar degeneration caused by high-dose cytosine arabinoside: A clinicopathological study. Ann. Neurol. 14: 520-527.

Yarchaon, R., R. V. Thomas, J.-P. Allain, N. McAtee, R. Dubinsky, H. Mitsuya, T. J. Lawley, B. Safai, C. E. Myers, C. F. Perno, R. W. Klecker, R. J. Wills, M. A. Fischl, M. C. McNeely, J. M. Pluda, M. Leuther, J. M. Collins, and S. Broder (1988) Phase I studies of 2', 3'dideoxycytidine in severe human immunodeficiency virus infection as a single agent and alternating with zidovudine (AZT). Lancet 1 : $76-81$.

Young, J. D., and S. M. Jarvis (1983) Nucleoside transport in animal cells. Biosci. Rep. 3: 309-322. 